\title{
Factors controlling the upper and lower limits of the intertidal distribution of two Corophium species in the Wadden Sea
}

\author{
J. J. Beukema, E. C. Flach* \\ Netherlands Institute for Sea Research, PO Box 59, 1790 AB Den Burg, Texel, The Netherlands
}

\begin{abstract}
On the tidal flats of the Dutch Wadden Sea, high densities of Corophium volutator (in silty areas) and of $C$. arenarium (in sandy areas) were limited to the upper parts of the intertidal zone. The upper limit was always situated close to the local level of high water at neap tides. After periods of higher- or lower-than-average water levels (caused by prevailing westerly or easterly winds, respectively), the zone of Corophium volutator distribution had shifted upward or downward, respectively. Conversely, the lower limits of high Corophium spp. densities did not show a consistent relation with intertidal level or duration of immersion but coincided with the upper level of high $\left(>10 \mathrm{~m}^{-2}\right)$ densities of adult lugworms Arenicola marina. In areas with sandy sediments (silt content < ca 15\%), this limit was situated about halfway between mean high water and mean tide level. In more muddy sediments, lugworms were scarce and high $C$. volutator densities extended to lower intertidal levels. It is concluded that zonation in the soft-bottom intertidal may generally be governed by the same processes as are prevalent in the rocky intertidal, viz. abiotic factors setting the upper limits and biotic interrelations setting the lower limits of species.
\end{abstract}

KEY WORDS: Intertidal zonation - Limiting factors - Water level S Species interactions · Corophium

\section{INTRODUCTION}

One of the main tasks of ecological research is to explain why species have limited areas of distribution. Species tend to occur only in restricted parts of environmental gradients. The species that inhabit the intertidal usually occupy only specific zones, i.e. they are abundant only in a part of the total tidal range, and this zone is generally characteristic of the species.

Generally, abiotic factors set limits to the range of a species within an environmental gradient. Outside the limits of occurrence of a species in, for instance, a climatic gradient, it is too cold or too hot, too dry or too wet, etc. Only within such abiotic limits can a species thrive. It is characteristic of these types of limitations that the area of distribution of a species shifts concurrently with a geographic shift in the gradient. For

\footnotetext{
- Present address: NIOO-CEMO, Vierstraat 28, 4401 EA Yerseke, The Netherlands
}

instance, species extend their area of distribution to higher latitudes if the climate becomes warmer, and intertidal species spread shoreward (i.e. to higher intertidal levels) if the sea level rises. In the intertidal zone, particularly the upper limit (mostly between the high tide and mean tide level) of intertidal marine species appears to be set by abiotic environmental factors such as prolonged exposure to air (causing desiccation or damage from ultraviolet radiation), extreme temperatures, and reduced feeding and respiration time. The lower limits of intertidal species, however, appear to be less strict, in accordance with the generally less harsh environmental conditions at the lower levels. The lower limits are usually between the mean tide and low tide level, where environmental conditions change less abruptly than at the uppermost intertidal levels.

In the rocky intertidal zone, several examples are available to show that the limiting factors at the upper and the lower end of the intertidal gradient differ: abiotic factors prevail at their upper end, whereas biological interactions (such as competition and preda- 
tion) prevail at the lower end (Menge \& Sutherland 1987). Examples of species limited such by differential limiting factors at the 2 ends of the intertidal gradient include: fucoid algae (Schonbeck \& Norton 1978, 1980), barnacles (Connell 1961, Menge 1976), and mussels (Seed \& Suchanek 1992). Examples to demonstrate this difference in the soft-bottom intertidal appear to be scarce. The study by Rakocinski et al. (1993) provides one.

The aim of the present paper is to explore which factors limit the intertidal zonation of the amphipods Corophium volutator (Pallas) and C. arenarium Crawford on tidal flats in the Dutch Wadden Sea. Do these species follow the general pattern described for the rocky intertidal by Menge \& Sutherland (1987) with a prevalence of abiotic control at the upper and biotic control at the lower levels?

Corophium volutator is generally numerous in the upper (coastal) parts of the intertidal flats of the Wadden Sea where the sediment is predominantly silty (Thamdrup 1935, Linke 1939, Smidt 1944, Jepsen 1965, Dankers \& Beukema 1983, Flach 1993), whereas $C$. arenarium is generally abundant where the sediment is sandy (Flach 1993). Densities of thousands or (in the case of $C$. volutator) tens of thousands per $\mathrm{m}^{2}$ are not uncommon in such areas. With the gastropod Hydrobia ulvae (Pennant) and the polychaete Nereis diversicolor O. F. Müller, a Corophium species often dominates the muddy upper tidal flats of the Wadden Sea. This zone is sometimes called the Corophium zone (Thamdrup 1935) or Corophium 'Assoziation' (Jepsen 1965). At silt contents below about 5\%, C. volutator is replaced by the related $C$. arenarium (Flach 1993), which in more silty areas is out-competed by C. volutator (Jensen \& Kristensen 1990).

The upper limit of Corophium spp. usually coincides with the seaward limit of dense Salicornia europaea covering (Gerdol \& Hughes 1993), which is around mean high water at neap tide. We hypothesise that the upper limit of Corophium spp. is directly related to the water level and is set by inundation frequency or duration. To test this hypothesis, we compare distribution patterns observed in various parts of the Wadden Sea (with different tidal ranges). Further, we examine whether Corophium spp. densities on Balgzand responded to natural variations in high water level during periods prior to sampling. In the Wadden Sea, this variation is particularly great in winter because of variation in wind directions. An extensive data set from long-term sampling at a large number of tidal flat stations on Balgzand, covering the entire intertidal range, is used to assess year-to-year shifts in the distribution zone of Corophium spp.

As to the lower limits of the distribution of the 2 Corophium species, results of experimental work sug- gest that they can occur in high numbers at all intertidal levels but that actual Corophium spp. densities are much reduced by the presence of other species. Several species of benthic animals have been found to exert negative influences on Corophium spp. abundance, either by competition for space or by predation. Among these species are lugworms Arenicola marina (L.) (Reise 1985, Brey 1991, Flach 1992a, b, Flach \& De Bruin 1993), cockles Cerastoderma edule (L.) (Jensen 1985, Flach 1992a, Flach \& De Bruin 1993), rag worms Nereis (Hediste) diversicolor (Bonsdorff et al. 1986, Ólafsson \& Persson 1986, Jensen 1988, Rönn et al. 1988, Jensen \& André 1993), and Macoma balthica (L.) (Jensen 1988, Hines et al. 1989). Therefore, we hypothesise that the lower limits of the Corophium species are set by the upper limits of high densities of other species. To test this hypothesis, we compare distribution patterns of Corophium species along transects perpendicular to the coast with those of the other species mentioned above.

\section{METHODS}

The zonation of the benthic macrofauna on Wadden Sea intertidal flats was studied by taking core samples along transects perpendicular to the coast. Every 20 or $50 \mathrm{~m}$, a core was taken and sieved in the field $11 \mathrm{~mm}$ meshes). Most of the data presented are from a longterm sampling programme on Balgzand, a tidal flat area in the westernmost part of the Wadden Sea (Fig. 1). This programme involves biannual sampling (in late winter and late summer) along 12 fixed transects of $1 \mathrm{~km}$ each with 50 samples ( $20 \mathrm{~m}$ apart) per transect. Individual cores were lumped per $100 \mathrm{~m}$ of transect; thus, data are available for 10 samples per transect. The total area sampled annually per transect amounted to $0.9 \mathrm{~m}^{2}$ in March (1.8 dm $\mathrm{dm}^{2}$ cores) and $0.45 \mathrm{~m}^{2}$ in August $\left(0.9 \mathrm{dm}^{2}\right.$ cores).

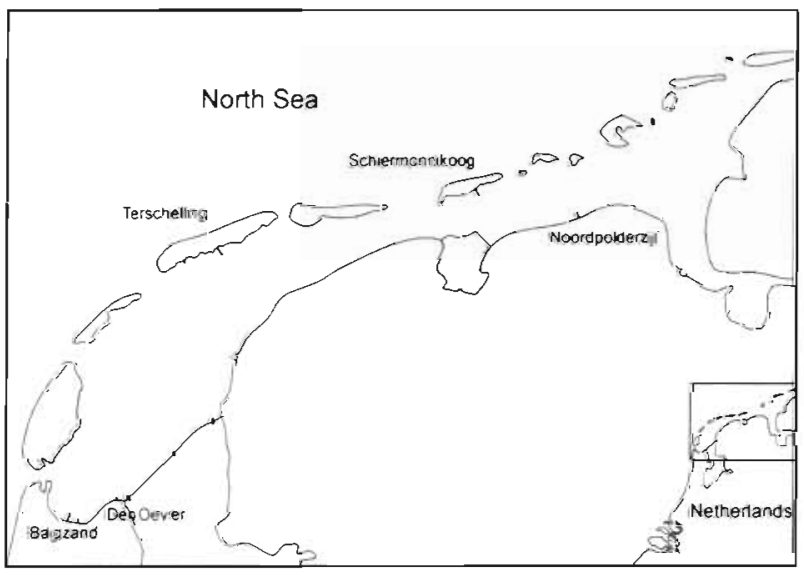

Fig. 1. The Dutch Wadden Sea showing locations of the transects mentioned in the text: 3 at Balgzand, 1 near Den Oever, 1 at Terschelling, 1 at Schiermonnikoog, and 1 at Noordpolderzijl 
Large numbers of Corophium spp. were regularly found along 3 out of the 12 Balgzand transects. These 3 transects run parallel (Fig. 1), and their levels partly overlap (compare Beukema 1993). Levels are expressed in dm above $(+)$ or below (-) mean tide level (MTL), which is close to the Dutch Ordinance Level. In the Balgzand area, average tides range from +6 (mean high water, MHW) to $-8 \mathrm{dm}$ (mean low water, MLW); at spring tides these levels are +7 and $-9 \mathrm{dm}$ and at neap tides +5 and $-7 \mathrm{dm}$, respectively. Strong easterly winds cause lower tides and strong westerly winds cause higher tides than expected from tide tables. Levels along transects were read from charts made available by Rijkswaterstaat, the former Studiedienst Hoorn. We used the soundings from 1980. Transect 1 runs from +4.5 to $+1 \mathrm{dm}$. Transect 2 from +3 to $-1 \mathrm{dm}$, and Transect 3 from -1 to $-8 \mathrm{dm}$. The distance between Transects 1 and 2 is slightly more than $1 \mathrm{~km}$, between Transects 2 and 3 about $300 \mathrm{~m}$. See Beukema (1993) for further details and a map. The sediments are predominantly silty along these transects, declining from about $30 \%$ silt (particles $<50 \mu \mathrm{m}$ ) at the higher levels to about $5 \%$ at levels well below MTL. Details on composition, species richness and biomass of the zoobenthos can be found in Beukema (1988).

In the long-term Balgzand programme, identification of Corophium spp. to the species level was routinely done only by taking random checks. Along Transects 1 and 2 only $C$. volutator were found; along Transect 3 the samples taken at levels above $-3 \mathrm{dm}$ (where silt contents were about $10 \%$ or higher) contained almost exclusively $C$. volutator, whereas below $-5 \mathrm{dm}$ the (low) numbers were all $C$. arenarium. Only results obtained during the period 1974 through 1990 were used, because in 1991 the $C$. volutator population on Balgzand collapsed, as it did over most of the Wadden Sea around 1991, probably as a consequence of trematode infection (Jensen \& Mouritzen 1992).

In other parts of the Wadden Sea, transects perpendicular to the coast were sampled at various places mapped in Flach (1993). Cores were taken at $50 \mathrm{~m}$ distances and sieved through $500 \mu \mathrm{m}$ meshes. At the same places, the numbers of lugworm castings were counted per $\mathrm{m}^{2}$ and the numbers of adult cockles per $0.25 \mathrm{~m}^{2}$. Corophium spp. were identified to the species level. Coastal tidal flats are generally muddy along the mainland coast and sandy along most of the coasts of the Frisian Islands. In accordance with this difference in sediment composition, C. volutator was numerous (thousands to tens of thousands per $\mathrm{m}^{2}$ ) only along the following transects indicated in Fig. 1: in the coastal part of Balgzand, off Den Oever (close to Balgzand), and at Noordpolderzijl (about $150 \mathrm{~km}$ east of Balgzand). In contrast, large numbers (hundreds per $\mathrm{m}^{2}$ ) of C. arenarium were found along a transect off the island of Schiermonnikoog, also about $150 \mathrm{~km}$ east of Balgzand [see Table 1 of Flach (1993) for further details on these transects]. From west to east, tidal ranges in the Dutch Wadden Sea increase: $14 \mathrm{dm}$ in the Balgzand area and 23 to $24 \mathrm{dm}$ near Schiermonnikoog and Noordpolderzijl. The levels of MHW in these areas are $+6 \mathrm{dm}$ and +10 to $+11 \mathrm{dm}$, respectively.

Monthly averages of MHW levels were obtained from Anonymous (1989) and from later separate annual issues of Jaarboek Monitoring Rijkswateren (Rijkswaterstaat, Den Haag). We used these data to estimate the MHW level during the 3 winter months preceding the annual samplings in March from 1974 to 1990. Data from the gauge at Den Helder were used, located at about $5 \mathrm{~km}$ from the 3 Corophium-rich Balgzand transects. From the detailed data collected in the Jaarboeken from 1986 to 1992 we estimated frequencies of flooding at various intertidal levels.

\section{RESULTS}

\section{Zonation of Corophium spp. in the Dutch Wadden Sea}

On Balgzand, maximum densities (mostly thousands of individuals per $\mathrm{m}^{2}$ ) were generally observed around or slightly below MTL. At that level, long-term averages of density peaked both in late winter (Fig. 2a) and in late summer (Fig. 2b). At higher and lower levels, mean densities rapidly declined to near-zero values where the levels approach the MHW $(+6 \mathrm{dm})$ and MLW $(-8 \mathrm{dm})$ marks. Though standard errors, reflecting year-to-year variation in abundance at the successive levels, were relatively high (Fig. $2 a$, b), the differences between densities at levels more than $2 \mathrm{dm}$ apart were generally statistically significant. Year-to-year variation in abundance was moderate at the higher densities, with coefficients of variation around 0.6 within the optimal tidal range between +2 and $-2 \mathrm{dm}$ (Fig, 2c, d). These coefficients increased to values around 1.0 at the higher $(+2$ to $+4 \mathrm{dm})$ and the lower levels $(-2$ to $-4 \mathrm{dm})$ where Corophium volutator occurred. The even higher coefficients at levels below $-4 \mathrm{dm}$ (Fig. 2c, d) do not concern C. volutator but reflect the annual variation in the rather erratic and low numbers of $C$. arenarium. Numbers of $C$. volutator were, thus, more variable at the higher than at intermediate and lower tidal levels.

A comparison of Fig. $2 \mathrm{a}$ and $\mathrm{b}$ shows that the high densities around and below MTL were on average only slightly (by 10 to $40 \%$ ) lower in winter than in summer. At the higher levels, however, seasonal differences were larger, with average winter densities less than half the summer densities. At the highest levels 

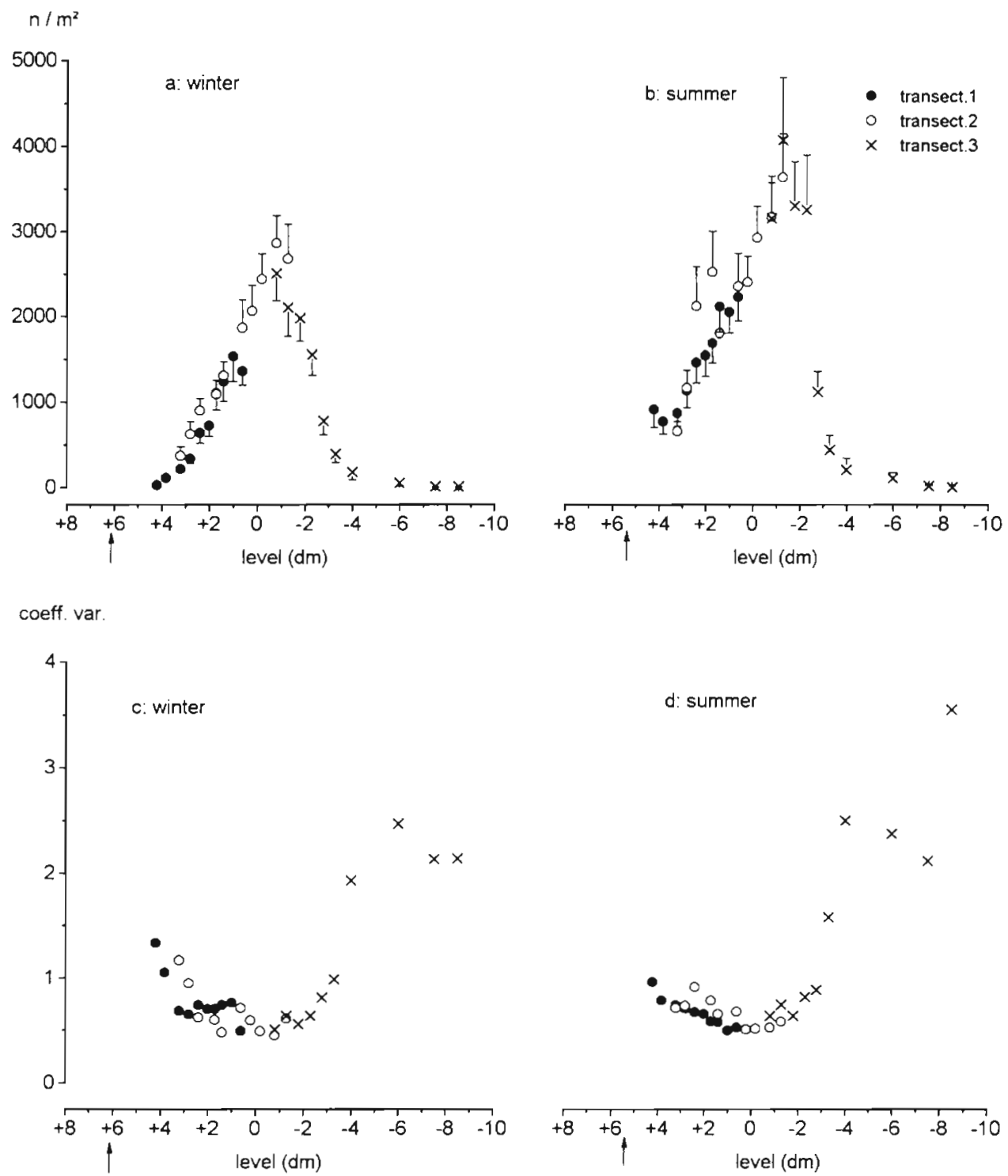

Fig. 2. Corophium volutator and C. arenarium. Relationship between intertidal level (in dm above and below mean tide level, MTL) and abundance (mean no. $\mathrm{m}^{-2}$ ) in (a) late winter and (b) late summer. Averages of 17 yr (1974 to 1990) with 1 standard error. At levels higher than about $-3 \mathrm{dm}$, nearly all specimens belonged to $C$. volutator, whereas below $-5 \mathrm{dm}$ all were $C$. arenarium. Graphs (c) \& (d) show relationships between level and coefficients of variation (standard deviation/mean) in late winter and late summer, respectively. Arrows indicate long-term mean high water (MHW) levels (which are slightly different in winter and summer

( $+4 \mathrm{dm}$ ) winter densities were only about $10 \%$ of those found there in summer. Thus, particularly at the higher intertidal levels, both the seasonal and the year-to-year variation was higher than at the optimal levels around MTL

Data from other parts of the Dutch Wadden Sea show that high densities of Corophium spp. were generally restricted to the upper part of the intertidal. On tidal flats off Den Oever (MHW $+6 \mathrm{dm}$ ), only about $10 \mathrm{~km}$ east of Balgzand, the distribution pattern of $C$. volutator was highly similar to that of Balgzand shown in Fig. 2: thou- sands per $\mathrm{m}^{2}$ between MTL and $+3 \mathrm{dm}$, but only a few at $+4 \mathrm{dm}$. In more eastern parts of the Dutch Wadden Sea, where MHW levels are higher, the zone of high C. volutator densities also shifts to higher levels compared to MTL. On the tidal flats off Terschelling (MHW $+8 \mathrm{dm}$ ) high densities were observed only around $+5 \mathrm{dm}$, and off Noordpolderzijl (MHW about $+11 \mathrm{dm}$ ) the zone of high densities extended from +8 to $+5 \mathrm{dm}$ (Fig. 3). High densities of $C$. arenarium were found off Schiermonnikoog (MHW level at about $+10 \mathrm{dm}$ ) at levels ranging from +7 to $+5 \mathrm{dm}$ (Fig. 4). Thus, the Corophium spp. zone ex- 


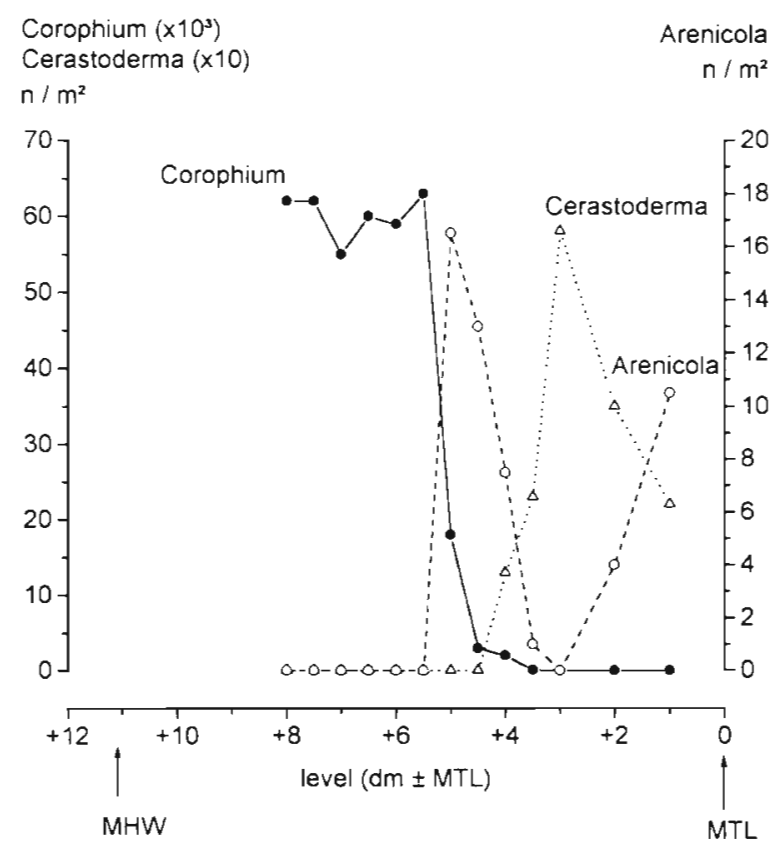

Fig. 3. Corophium volutator, Arenicola marina and Cerastoderma edule. Relationship between intertidal level (in $\mathrm{dm}$ above MTL) and numerical abundance (no. $\mathrm{m}^{-2}$ ) of 3 species along a transect near Noordpolderzijl: $(\bullet \bullet)$ the amphipod $C$. volutator (in thousands $\mathrm{m}^{-2}$ ); (0---0) the lugworm $A$. marina

(in no. $\mathrm{m}^{-2}$ ); and $(\Delta \cdots \Delta)$ the cockle $C$. edule (in tens $\mathrm{m}^{-2}$ )

tends from an upper level that is similar everywhere, viz. a few dm below the local MHW level, to a lower limit that is highly variable: from below MTL to about halfway between MTL and MHW.

\section{Conditions around the upper level of Corophium spp.}

At levels of about $3 \mathrm{dm}$ below the local MHW level, Corophium spp. were plentiful everywhere along our Corophium-rich transects. At $2 \mathrm{dm}$ below this level their numbers were significantly smaller, and at $1 \mathrm{dm}$ below the local MHW level they were scarce or absent. The level of MHW at neap tides is 1 to $2 \mathrm{dm}$ below the MHW level of all tides. This we consider to be the upper limit of Corophium spp. Apparently they need a minimum frequency or duration of water coverage. At the upper limit, mean water coverage is between 10 and $20 \%$ of the year. However, marine animals living there do not experience such water coverage every day, week or even month. Actual weekly durations of immersion at this level are highly variable (from 0 to $100 \%$, depending on season, neap and spring tides and above all on the prevailing direction of strong winds. Therefore, for any given tidal level it is more meaningful to state the proportion of tides during which that level remains dry. This is particularly so in the western part of the Wadden Sea, where the tidal curve has an aberrant shape: its top part is very flat and the high water (HW) period lasts several hours at a level close to the HW level of that day. Thus, organisms living at high intertidal levels in this area generally experience either a completely dry tidal cycle or immersion for several hours in succession around the time of HW, but shorter immersion periods are rare.

The $+4 \mathrm{dm}$ level at Balgzand, where Corophium volutator densities decreased (particularly in winter, Fig. 2a), remained dry during about $20 \%$ of all $\mathrm{HW}$ periods which occurred during the 7 yr period 1986 to 1992. Especially in winter months, when wind forces tend to be higher than in summer, this proportion of low floods was highly variable. In our sample of 21 winter months (December, January, and February of the 7 years 1986 to 1992), it ranged from 6 to $60 \%$ of the about 60 monthly HW periods. In about half of these winters, long continuous periods of low HW levels occurred, including more than 10 successive tides not reaching the $+4 \mathrm{dm}$ level. Conditions at the upper limit of $C$. volutator are, thus, highly variable and include the frequent accurrence of prolonged periods without immersion.

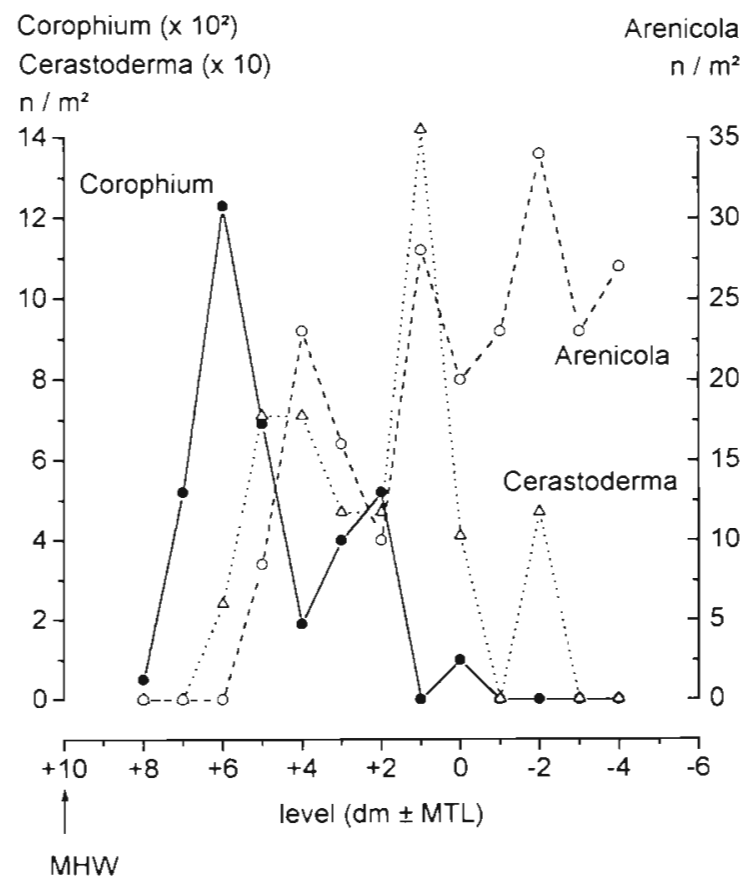

Fig. 4. Corophium arenarium, Arenicola marina and Cerastoderma edule. Relationship between intertidal level (in $\mathrm{dm}$ above and below MTL) and numerical abundance (no. $\mathrm{m}^{-2}$ ) of 3 species along a transect off Schiermonnikoog: $(\bullet)$ the amphipod $C$. arenarium (in hundreds $\mathrm{m}^{-2}$ ); (0---O) the lugworm $A$. marina (in no. $\mathrm{m}^{-2}$ ); and $(\Delta \cdots \Delta)$ the cockle $C$. edule (in tens $\mathrm{m}^{-2}$ ) 


\section{Annual variation of Corophium volutator zonation with water level}

We ranked the 17 winters of the observation period 1974 to 1990 in order of declining MHW levels during the December/January/February period and compared the distribution patterns found in March along the Balgzand Transects 1 and 2 and part of Transect 3 (data from the lower and sandy part of Transect 3 were omitted because they refer to Corophium arenarium). After the 4 winters with the lowest MHW levels, the $C$. volutator zone had shifted to lower intertidal levels than after the 4 winters with the highest water levels (Fig. 5). Total numbers of $C$. volutator hardly differed and were not related to the foregoing water levels or to foregoing temperatures (winters with low water levels are characterised by prevailing easterly winds and low temperatures). Thus, at similar total numbers, more individuals were living at high levels and fewer at low levels when water levels had been high during the foregoing months. When water levels had been low, reduced numbers were found at levels of $+1 \mathrm{dm}$ or higher (the upper parts of Transects 1 and 2) and enhanced numbers at levels below MTL (Transect 3). In this way, the centre of the $C$. volutator zone shifted

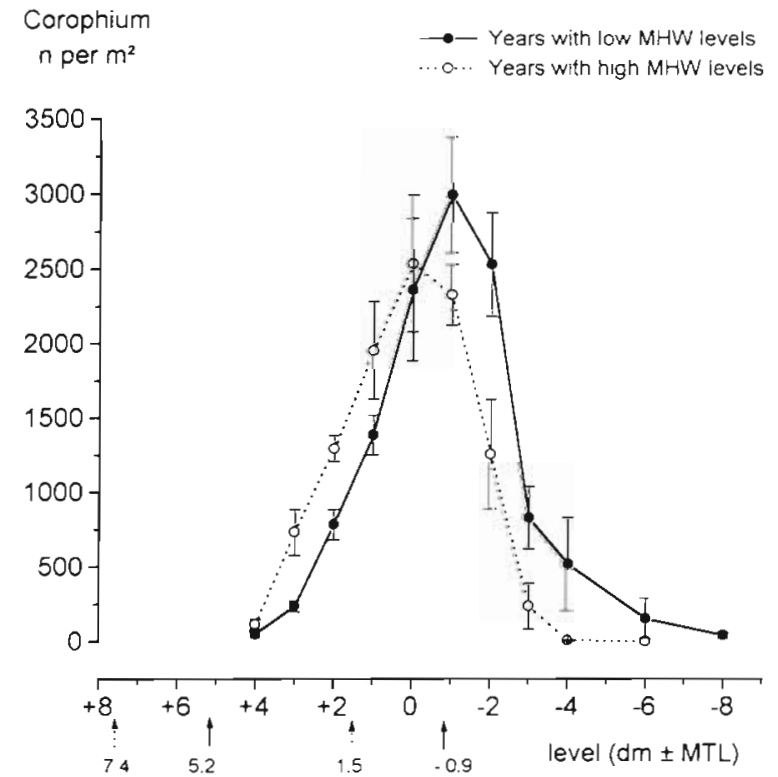

Fig. 5. Corophium volutator. Abundance (mean no. $\mathrm{m}^{-2}$ with $1 \mathrm{SE}$ ) at various intertidal levels (in $\mathrm{dm}$ above and below MTL) as observed in March in 2 groups of 4 years: $(\bullet)$ after the 4 winters (December/January/February) with the lowest mean water levels of the 1974 to 1990 period (on average MHW and mean water level were $52 \mathrm{~cm}$ above and $9 \mathrm{~cm}$ below long-term MTL); and (0---o) after 4 winters with the highest water levels (MHW and mean water level 74 and $15 \mathrm{~cm}$ above long-term MTL, respectively)

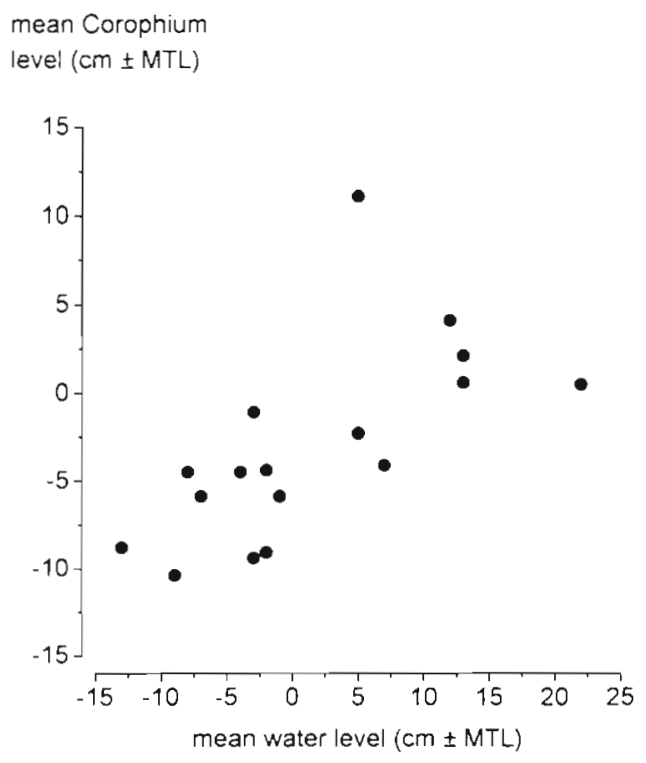

Fig. 6. Corophium volutator. Relationship between mean water level (cm below and above MTL) in the December/ January/February periods of 17 winters (1974 to 1990) and the subsequent mean level of occurrence of $C$. volutator as observed in March at Transects 1,2 and 3. The correlation is significantly positive $(r=+0.75, n=17, p<0.01$, Spearman test)

in the same direction as the mean water level did during the foregoing months.

The centre of the distribution zone was estimated in March of each year by calculating the mean level of all Corophium volutator found along the 3 transects. As expected from the shift shown in Fig. 5, the centre of the $C$. volutator distribution was positively correlated with the MWL of the foregoing 3 mo period (Fig. 6). Note that the shift in the C. volutator zone amounted to only about half of the variation in water levels.

\section{Lower limits of the intertidal distribution of Corophium spp.}

Densities of Corophium volutator not only decreased towards high tidal levels, even steeper declines were observed towards the lower part of their zone. On Balgzand, the latter decline became evident at levels of about $-2 \mathrm{dm}$ (Fig. $2 \mathrm{a}$, b). In more easterly areas, this decline occurred at higher levels: at about $+2 \mathrm{dm}$ off Terschelling and at about $+5 \mathrm{dm}$ at Noordpolderzijl (Fig. 3), and in C. arenarium at $+4 \mathrm{dm}$ off Schiermonnikoog (Fig. 4). In all of these areas, Corophium spp. densities came close to nil at only slightly lower (about $2 \mathrm{dm}$ ) levels. The lower limits were, thus, rather different in the different parts of the Dutch Wadden Sea They did not bear any clear relationship to flooding 
characteristics. On Balgzand the $-2 \mathrm{dm}$ level is $8 \mathrm{dm}$ below MHW (i.e. $60 \%$ of the total local tidal range of $14 \mathrm{dm}$ ), whereas at Noordpolderzijl the corresponding Corophium volutator level of $+5 \mathrm{dm}$ is $6 \mathrm{dm}$ below MHW (i.e. only $25 \%$ of the local tidal range of $24 \mathrm{dm}$ ). This suggests that other factors than duration or frequency of immersion set the lower limit of the Corophium spp. distribution.

Factors other than water levels that could limit the downward distribution of Corophium spp. are indicated by our earlier reported results of density manipulations in the field. When lugworms and cockles were removed from areas below the lower limits of Corophium spp., both C. volutator (Flach 1992a, Flach \& De Bruin 1993) and C. arenarium (Flach 1993) rapidly invaded such areas and reached high densities. Further, the higher the densities of (restocked) lugworms or cockles, the lower were the final densities of Corophium spp. These results of local field experiments strongly suggest that Corophium spp. can live in high densities at lower intertidal levels than they actually do, but that it is the presence of lugworms or cockles that prevents them from actually occupying such areas.

In the following, by transect sampling in various parts of the Wadden Sea, we show that the lower levels where Corophium spp. densities were low indeed coincided with the upper levels of high densities of lugworms and cockles. In 3 areas (Balgzand, Noordpolderzijl, and Schiermonnikoog) we found particularly large numbers of Corophium spp. along our transects and results from these areas are used.

Along the Corophium-rich transects on Balgzand. densities of $C$. volutator were low where the lugworm densities were high (Fig. 7 a). The densities of $C$, volutator were dramatically lower (less than 100 instead of $2500 \mathrm{~m}^{-2}$ ) where lugworm densities were about 60 instead of about $10 \mathrm{~m}^{-2}$. Cockles were almost entirely absent along these Balgzand transects. Distribution patterns of other species (Nereis diversicolor, Macoma balthica) that were inferred by some authors to reduce Corophium spp. abundance did not show any clear relationship with patterns of $C$. volutator (Fig. $7 \mathrm{~b}$ ). The distribution pattern of $N$. diversicolor showed maximum values around MTL and was similar to that of $C$. volutator (compare Fig. $7 \mathrm{a}$ and b). The densities of $M$. balthica increased only slowly over the levels where $C$. volutator steeply declined. Thus, only lugworm densities showed the clearly reverse distribution pattern (Fig. 7a) that may be expected in a species interfering seriously with $C$. volutator.

At Noordpolderzijl, all 3 species (Corophium volutator, Arenicola marina and Cerastoderma edule) that had proved to be relevant on Balgzand were present in sufficient numbers (Fig. 3). The steep decline of $C$. volutator numbers at $+5 \mathrm{dm}$ coincided with the upper level of lugworms. As was the case on Balgzand, $C$. volutator densities declined steeply exactly at the level where lugworm numbers increased rapidly. At a level
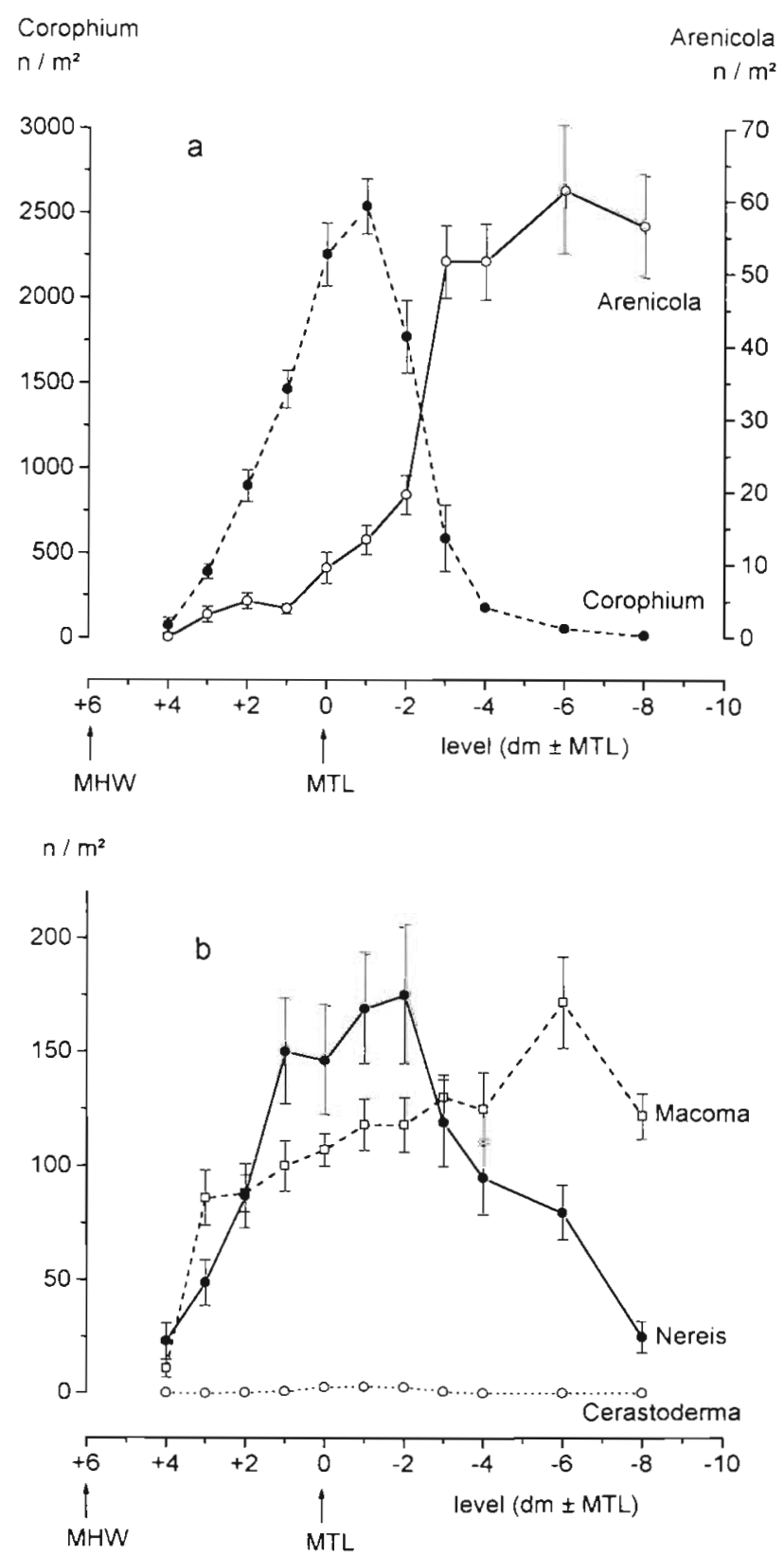

Fig. 7. Relationships between intertidal level (dm above and below MTL) and numerical abundance (no. $\mathrm{m}^{-2}$, with $1 \mathrm{SE}$ ) of a number of important species in the coastal part of Balgzand: (a) Corophium volutator ( $\bullet$ ) and Arenicola marina (O); (b) Cerastoderma edule (o), Nereis diversicolor ( $\bullet$ ), and adult Macoma balthica (a). Local level of MHW indicated. Data refer to 3 transects (detailed data on Corophium spp. in Fig. 2a) sampled annually during the 1974 to 1990 period; standard errors reflect year-to-year variability $(n=17)$ 
around $+3 \mathrm{dm}$, where lugworm densities happened to be low, $C$. volutator numbers did not increase. However, at this level cockles were abundant $\left(>100 \mathrm{~m}^{-2}\right.$, Fig. 3).

Off Schiermonnikoog, the densities of Corophium arenarium declined steeply at a level of about $+5 \mathrm{dm}$. Densities of both lugworms and cockles started to increase at this level: (adult) lugworms to some tens per $\mathrm{m}^{2}$ and cockles to several tens per $\mathrm{m}^{2}$ (Fig. 4). Note that $C$. arenarium showed a second peak at $+2 \mathrm{dm}$ where densities of both lugworms and cockles were relatively low.

\section{DISCUSSION}

In the Wadden Sea, the 2 Corophium species showed a clear zonation with maximum densities generally restricted to the upper part of the intertidal zone but below the HW neap-tide level. The factors limiting their distribution to such a restricted zone appear to follow the general model described for the rocky intertidal by Menge \& Sutherland (1987): the upper limit is set by the physiological ability to survive during the harsh conditions of prolonged emersion, whereas the lower limit is determined by the outcome of interactions with other species.

The upper limit of Corophium spp., near the local MHW neap-tide level, appears to be set by a minimal duration of immersion. The evidence is 2 -fold: (1) in different areas, the elevation of this limit above MTL is different, but the relation to MHW is consistent, i.e. the minimal duration of immersion is similar; and (2) in the same area, this limit shifts to a higher elevation after periods of elevated water levels (Figs. $5 \& 6$ ). In the marginal area close to $\mathrm{MHW}$, numbers of Corophium volutator fluctuated more strongly than at the lower intertidal levels where densities are higher (Fig. 2). This was particularly so in winter, the harsh season with long periods of continuous emersion of the upper zone because of easterly winds.

Few examples appear to be available for the softbottom intertidal to show that lower limits are set by interrelationships with other species (Peterson 1991), probably because competition for space is a less dominant process there than on rocky shores (Black \& Peterson 1988). In the case of Corophium spp., however, several benthic species are known to reduce the local abundance of these tiny amphipods that live in burrows vulnerable to sediment disturbance (Thamdrup 1935). The most important among these species appears to be the lugworm Arenicola marina (Reise 1985, Brey 1991, Flach 1992a, b). The opposing distribution patterns shown in Figs. 3, 4 \& 7a suggest that even low densities of a few tens of adult lugworms $\mathrm{m}^{-2}$ effectively reduce Corophium spp. densities. A severe effect by low densities of lugworms was demonstrated experimentally by Flach $(1992 a, 1993)$. The intensive sediment-reworking activities of lugworms (Cadée 1976) drive C. volutator out of their burrows, where they are prone to predation (Flach \& De Bruin 1994), or burrow into the sediment at a different place (Flach 1992b). Lugworms show densities of $>10 \mathrm{~m}^{-2}$ regularly distributed over vast areas in the Dutch Wadden Sea, and their densities are also remarkably constant over long periods (Beukema \& De Vlas 1979, Dankers \& Beukema 1983, Flach \& Beukema 1994).

Cockles Cerastoderma edule can play a similar role in reducing numbers of Corophium spp., but they are effective only at relatively high densities (several hundreds per $\mathrm{m}^{2}$; Flach 1992a, 1993) that occur rarely over vast areas in the Dutch Wadden Sea (Beukema 1976, Dankers \& Beukema 1983). Therefore, cockles will affect Corophium spp. numbers only locally in the Dutch Wadden Sea (an example may be the situation at the $+3 \mathrm{dm}$ level in Fig. 3). In contrast, in the Danish part of the Wadden Sea, vast areas may have high densities of cockles over prolonged periods (Jensen 1992). Thamdrup (1935) noted that high densities of C. volutator did not occur when cockles were plentiful but might occur at any level when cockles were scarce. Species other than lugworms and cockles appear to play only a minor role in limiting Corophium spp. abundance (Macoma balthica and Nereis diversicolor Fig. 7b). This would be in accordance with the results of density-manipulation experiments on Balgzand: even higher-than-normal densities of $M$. balthica exerted only a slight and statistically non-significant negative influence on $C$. volutator densities, and high $N$. diversicolor densities had no negative effects at all (Flach 1992a).

Adult lugworms are particularly abundant at levels around and below MTL (Beukema \& De Vlas 1979, Farke et al. 1979, Dankers \& Beukema 1983), leaving only the upper intertidal levels free from intensive bioturbation. Due to their even distribution and constant presence at effective densities, they will exert a continuous pressure on Corophium spp. to move upward in the tidal zone. Simultaneously, prolonged emersion will exert a pressure in the opposite direction. The high mobility of C. volutator (Essink et al. 1989, Hughes \& Horsfall 1990) will enable them to quickly adapt their distribution to these opposing pressures, as shown in Figs. $5 \& 6$.

We found differential levels at which lugworms restricted the downward distribution of Corophium spp. in different parts of the Dutch Wadden Sea: at about $-2 \mathrm{dm}$ on Balgzand (Fig. 7) for C. volutator and at about $+5 \mathrm{dm}$ off Schiermonnikoog (C. arenarium, Fig. 4) and Noordpolderzijl (C. volutator, Fig. 3). The 
$+5 \mathrm{dm}$ level is about halfway between the local MHW and MTL levels and this appears to be the upper limit of adult lugworms; above such halfway levels we found only juveniles. However, along the Balgzand transects, adult lugworms did not occupy such high intertidal levels (Fig. 7a), probably because the sediment of the higher zone is relatively silty, as a consequence of its sheltered location in the lee of westerly winds. Lugworms are known to avoid areas with silt contents $>10$ to 20\% (Beukema \& De Vlas 1979, Dankers \& Beukema 1983). Such a silt-content limit is indeed situated around $-2 \mathrm{dm}$ in the Balgzand transects. At the (sparse) locations on Balgzand where this silt-content limit is situated at higher levels (between -2 and $+2 \mathrm{dm}$ ), adult lugworms were found in densities of tens per $\mathrm{m}^{2}$ (up to $+2 \mathrm{dm}$, i.e. almost halfway between the local MHW and MTL). In such areas Corophium spp. densities were low (see Fig. 2 of Flach 1993). Thus, also at Balgzand, the upper limit of adult lugworms is situated about halfway between MHW and MTL wherever silt contents permit. C. volutator can extend to lower levels only where silt contents are well above $10 \%$. The silt content where $C$. arenarium starts to replace $C$. volutator is even lower (generally around $5 \%$ silt).

As lugworms are known to negatively affect a high number of infaunal species on tidal flats (Flach 1992b), we expect that more species will be more or less restricted to areas that are unsuitable for adult lugworms. The restriction of juvenile lugworms to areas with low adult densities (Flach \& Beukema 1994) is an example. Maximum densities of juvenile lugworms are generally found in the upper zone of the intertidal (above the zone of high densities of adults), the socalled nursery areas or 'Brutwatten' (Wohlenberg 1937. Beukema \& De Vlas 1979 and references therein, Farke et al. 1979). This is another example of a clear zonation in the soft-bottom intertidal.

In the German (Linke 1939, Jepsen 1965) and Danish (Thamdrup 1935, Smidt 1944) parts of the Wadden Sea, the zonation of Corophium spp. appears to be similar to the patterns described above for the Dutch Wadden Sea. Thamdrup (1935) states that the upper limit coincides with short daily periods of water coverage ( $10 \%$ of the time), which is close to values found in the Dutch Wadden Sea. As in the Dutch Wadden Sea, the lower limits of Corophium spp. often coincide with the higher limits of substantial densities of lugworms (compare e.g. Figs. 49 to 54 with Figs. 57 to 62 in Thamdrup 1935). Such coincidences of strong increases of lugworm densities with steep declines in $C$. volutator densities were also observed in shallow bays along the Swedish west coast. In the summer of a year with relatively high water levels (1993), high lugworm densities extended to a zone closer to the coast than in a year with low water levels (1992). Accordingly, the $C$. volutator zone above this lugworm zone was narrower in 1993 than in 1992 (see Fig. 11 of Flach \& De Bruin 1993). Thus, the lugworm-governed limitation of Corophium spp. to the higher intertidal levels is not limited to the Wadden Sea.

Acknowledgements. We thank Wim de Bruin, Jaap Zuidewind and the crews of the research vessels 'Griend' and 'Navicula' for their assistance in the field work

\section{LITERATURE CITED}

Anonymous (1989) Tienjarig overzicht der waterhoogten, afvoeren en watertemperaturen 1971-1980. Rijkswaterstaat, 's Gravenhage

Beukema JJ (1976) Biomass and species richness of the macro-benthic animals living on the tidal flats of the Dutch Wadden Sea. Neth J Sea Res 10:236-261

Beukema JJ (1988) An evaluation of the ABC method (abundance/biomass comparison) as applied to macrozoobenthic communities living on tidal flats in the Dutch Wadden Sea. Mar Biol 99:425-433

Beukema JJ (1993) Successive changes in distribution patterns as an adaptive strategy in the bivalve Macoma balthica (L.) in the Wadden Sea. Helgoländer Meeresunters 47 : 287-304

Beukema JJ, De Vlas J (1979) Population parameters of the lugworm, Arenicola marina, living on tidal flats in the Dutch Wadden Sea. Neth J Sea Res 13:331-353

Black R, Peterson CH (1988) Absence of pre-emption and interference competition for space between large suspension-feeding bivalves and smaller infaunal macroinvertebrates. J exp mar Biol Ecol 120:183-198

Bonsdorff E, Matilla J, Rönn C, Österman CS (1986) Multidimensional interactions in shallow soft-bottom ecosystems; testing the competitive exclusion principle. Ophelia $4: 37-44$

Brey T (1991) The relative significance of biological and physical disturbance: an example from intertidal and subtidal sandy bottom communities. Estuar coast Shelf Sci 33: $339-360$

Cadée GC (1976) Sediment reworking by Arenicola marina on tidal flats in the Dutch Wadden Sea. Neth J Sea Res 10:440-460

Connell JH (1961) Effects of competition, predation by Thais lapillus, and other factors on natural populations of the barnacle Balanus balanoides. Ecol Monogr 31:61-104

Dankers N, Beukema JJ (1983) Distributional patterns of macrozoobenthic species in relation to some environmental factors. In: Wolff WJ (ed) Ecology of the Wadden Sea, Vol 1, No. 4. Balkema, Rotterdam, p 69-103

Essink K, Kleef HL, Visser W (1989) On the pelagic occurrence and dispersal of the amphipod Corophium volutator. J mar biol Ass UK 69:11-15

Farke H, De Wilde PAWJ, Berghuis EM (1979) Distribution of juvenile and adult Arenicola marina on a tidal mud flat and the importance of nearshore areas for recruitment. Neth J Sea Res 13:354-361

Flach EC (1992a) The influence of four macrozoobenthic species on the abundance of the amphipod Corophium volutator on tidal flats of the Wadden Sea. Neth J Sea Res 29: $379-394$ 
Flach EC (1992b) Disturbance of benthic infauna by sediment-reworking activities of the lugworm Arenicola marina. Neth J Sea Res 30:81-89

Flach EC (1993) The distribution of the amphipod Corophium arenarium in the Dutch Wadden Sea. Neth J Sea Res 31: $281-290$

Flach EC, Beukema JJ (1994) Density-governing mechanisms in populations of the lugworm Arenicola marina on tidal flats. Mar Ecol Prog Ser 115:139-149

Flach EC, De Bruin W (1993) Effects of Arenicola marina and Cerastoderma edule on distribution, abundance and population structure of Corophium volutator in Gullmarsfjorden, western Sweden. Sarsia 78:105-118

Flach EC, De Bruin W (1994) Does the activity of cockles, Cerastoderma edule (L.) and lugworms, Arenicola marina L., make Corophium volutator Pallas more vulnerable to epibenthic predators: a case of interaction modification? J exp mar Biol Ecol 182:265-285

Gerdol V, Hughes RG (1993) Effect of the amphipod Corophium volutator on the colonisation of mud by the halophyte Salicornia europaea. Mar Ecol Prog Ser 97:61-69

Hines AH, Posey MH, Haddon PJ (1989) Effects of adult suspension- and deposit-feeding bivalves on recruitment of estuarine infauna. Veliger 32:109-119

Hughes RG, Horsfall IM (1990) Differences in the swimming behaviour of the amphipod Corophium volutator from different populations. J mar biol Ass UK 70:143-148

Jensen KT (1985) The presence of the bivalve Cerastoderma edule affects migration, survival and reproduction of the amphipod Corophium volutator. Mar Ecol Prog Ser 25: $269-277$

Jensen KT (1988) Recruitment and survival of Nereis diversicolor O. F. Müller and Corophium volutator (Pallas) in an artificial salt water lagoon in the Danish Wadden Sea. Kieler Meeresforsch (Sonderh) 6:366-374

Jensen KT (1992) Dynamics and growth of the cockle, Cerastoderma edule, on an intertidal mud-flat in the Danish Wadden Sea: effects of submersion time and density. Neth J Sea Res 28:335-345

Jensen KT, André C (1993) Field and laboratory experiments on interactions among an infaunal polychaete, Nereis diversicolor, and two amphipods, Corophium volutator and $C$. arenarium: effects on survival, recruitment and migration. J exp mar Biol Ecol 168:259-278

Jensen KT, Kristensen LD (1990) A field experiment on competition between Corophium volutator (Pallas) and Corophiurn arenarium Crawford (Crustacea: Amphipoda): effects on survival, reproduction and recruitment. J exp mar Biol Ecol 137:1-24

Jensen KJ, Mouritzen KN (1992) Mass mortality in two

This article was submitted to the editor common soft-bottom invertebrates, Hydrobia ulvae and Corphium volutator - the possible role of trematodes. Helgoländer Meeresunters 46:329-339

Jepsen U (1965) Die Struktur der Wattenbiozönosen im Vormündungsgebiet der Elbe. Arch Hydrobiol (Suppl) 24: $252-370$

Linke O (1939) Die Biota des Jadebusenwattes. Helgoländer wiss Meeresunters 1:201-348

Menge BA (1976) Organization of the New England rocky intertidal community: role of predation, competition, and environmental heterogeneity. Ecol Monogr 46:355-393

Menge BA, Sutherland JP (1987) Community regulation: variation in disturbance, competition, and predation in relation to environmental stress and recruitment. Am Nat 130 $730-757$

Olatsson EB, Persson LE (1986) The interaction between Nereis diversicolor O. F. Müller and Corophium volutator Pallas as a structuring force in shallow brackish sediment. J exp mar Biol Ecol 103:103-117

Peterson $\mathrm{CH}$ (1991) Intertidal zonation of marine invertebrates in sand and mud. Am Scient 79:236-249

Rakocinski CF, Heard RW, LeCroy SE, McLelland JA, Simons $T$ (1993) Seaward change and zonation of the sandy-shore macrofauna at Perdido Key, Florida, U.S.A. Estuar coast Shelf Sci 36:81-104

Reise K (1985) Tidal flat ecology. Springer-Verlag, Berlin

Rönn C, Bonsdorff E, Nelson WG (1988) Predation as a mechanism of interference within infauna in shallow brackish water soft bottoms; experiments with an infaunal predator, Nereis diversicolor O. F. Müller. J exp mar Biol Ecol 116:143-157

Schonbeck M, Norton TA (1978) Factors controlling the upper limits of fucoid algae on the shore. J exp mar Biol Ecol 31: 303-313

Schonbeck M, Norton TA (1980). Factors controlling the lower limits of fucoid algae on the shore. J exp mar Biol Ecol 43 : $131-150$

Seed R, Suchanek TH (1992) Population and community ecology of Mytilus. In: Gosling E (ed) The mussel Mytilus: ecology, physiology, genetics and culture. Elsevier, Amsterdam, p 87-169

Smidt ELB (1944) Das Wattenmeer bei Skallingen, No 3. The effects of ice winters on marine littoral fauna. Folia Geogr Danica 2(3):1-36

Thamdrup HM (1935). Beiträge zur Ökologie der Wattenfauna auf experimenteller Grundlage. Meddr Kommn Danm Fisk Havunders (Ser Fiskeri) 10(2):3-125

Wohlenberg E (1937) Die Wattenmeer-Lebensgemeinschaften in Königshafen von Sylt. Helgoländer wiss Meeresunters 1:1-92

Manuscript first received: December 19, 1994

Revised version accepted: March 15, 1995 